\title{
Challenges Facing Humanitarian Assistance in Conflict-affected Areas of Myanmar
}

\author{
Kai Chen \\ School of International Relations, Xiamen University, Xiamen 361002, China \\ kaichen@xmu.edu.cn
}

\begin{abstract}
Keywords: Humanitarian Assistance; Myanmar; Ethnic-based Militias; Conflict-affected Area; Public-private Partnership.
\end{abstract}

Abstract. With the aim of exploring challenges facing humanitarian assistance in conflict-affected areas of Myanmar, this article explores the following three challenges: limited access to conflict-affected areas, continued resentment towards foreign investment, and privatization of security. In response to these challenges, as this article suggests, public-private partnership should be an alternative option, which could ensure more effective and sustainable provision of humanitarian assistance in the foreseeable future.

\section{Introduction}

After the decades-old ethnic conflicts, the Myanmar government and ethnic-based militias in the borderlands, did not reach a political sustainable agreement to address the fundamental causes behind the conflicts, including but not limited to form of governance, and power sharing. Both parties persist in having a voice in decision-making, through legitimate institutions or organizations that represent their interests. The future of humanitarian assistance in the conflict-affected areas of Myanmar might be less predictable.

In the meantime, the past decades witnessed that humanitarian assistance in the conflict-affected areas of Myanmar has expanded both in size and geographical coverage. This article stresses the challenges facing humanitarian assistance, that is, limited access to conflict-affected areas, continued resentment towards foreign investment, and privatization of security. Moreover, as the author suggests, public-private partnership should be an alternative solution to the mentioned-above challenges in the coming future.

\section{Challenges Facing Humanitarian Assistance}

\subsection{Limited Access to Conflict-affected Areas}

In many conflict-affected areas of Myanmar, the Myanmar government is not present or is only represented by the Myanmar Army (Tatmadaw), while the ethnic-based militias usually enjoy more local recognition than that of the Myanmar Army. At the same time, the potential tensions between the Myanmar Army and ethnic-based militias have prevented humanitarian organizations from transporting relief supplies to the vulnerable population in the conflict-affected areas. For instance, they used checkpoints to "assert territorial control and raise revenue has been a persistent obstacle to the delivery of assistance" [1].

In the conflict-affected areas, the available relief supplies are often delivered and distributed by the non-state actors, many of which are local organizations associated with the ethnic-based militias [2]. What's worse, at least 17 non-state armed organizations have used landmines since 1999, including the Karen National Liberation Army (KNLA), the Karenni Army, the Democratic Karen Buddhist Army (DKBA), and the Kachin Independence Organization / Army (KIO / KIA) [3]. In the conflict-affected areas of Myanmar, there is almost no village without a landmine victim [4].

In 2016, there has been little progress on the landmine issue in the conflict-affected areas. More than 40 townships across Myanmar are still threatened by landmines. According to Thai News Service, seven demining organizations from western countries arrived in Myanmar, which are still 
awaiting the government's permission [5]. However, the casualty caused by landmines continues. In April 2016, two German travelers and their local guide were wounded by a landmine in a conflict-affected area of north Myanmar [6].

\subsection{Continued Resentment Towards Foreign Investment}

The lifting of international sanctions in Myanmar has led to many transnational corporations' growing interests of investment in the country. In general, Myanmar has two things that transnational corporations desperately want, that is, industrious population and abundant natural resources. In Myanmar, most of the skirmishes in the borderlands (e.g., Kachin State and northern Shan State) have centered on natural resources, and the winners will "sell the resources under their control to international markets” [7].

Theoretically, foreign investment might be helpful to humanitarian assistance to some extent. The country drew 9.5 billion USD foreign investment in the fiscal year 2015-2016 [8]. However, they will also lead to more ethnic conflicts in the borderlands, in which there are large amounts of vacant lands. In some cases, some projects (e.g., infrastructure and extraction of resources) financed by foreign investment have led to large-scale land acquisition, and caused displacement of local communities in the borderlands. Historically, the vacant lands were the ancestral lands of the ethnic communities, who have no official property rights of land. In response to the growing opposition to land laws and land grabs, the Protecting Rights and Enhancing Economic Welfare of Farmers Law was finally approved on October 3rd 2013, it barely rated a mention in Myanmar's media. This law aims at protecting the interests of middle and large-income rural households. It does not mention land rights or tenure security for smallholders [9].

During the past decade, the Myanmar government has transmitted the mentioned-above ancestral lands to the foreign investors. With no doubt, the foreign investment stimulated ethnic conflicts in the borderlands, as well as triggered resentment towards foreign investors, such as the Dawei Port Project, the Kaladan Multi-modal Transit Transport Project, the Shwe Gas Project, and the Zawtika project located in the Gulf of Martaban.

\subsection{Privatization of Security}

The privatization of security is a global trend, which encourages greater partnership between humanitarian organizations and private security contractors, particularly in a context that a state's monopoly over the legitimate use of force is limited, or a state has limited resources in dealing with security issues caused by non-state actors (e.g., Insurgents and militias). In such a case, many stakeholders (e.g., transnational corporations and NGOs) have become less dependent upon the Myanmar government for protection in the conflict-affected areas, and hire private security contractors to guarantee their own interests.

In Myanmar, the private security contractors are normally paid between 40,000 Kyat and 45,000 Kyat (33-37 USD) per month [10]. In addition, a private security company named "Phoenix Elite Security Services", assisted the Myanmar government to draft the new national standards for private security companies [11].

Moreover, in the conflict-affected areas of Myanmar, the reclaiming of a completely neutral space for all humanitarian assistance is an unrealistic goal [12]. For example, humanitarian organizations like CARE International and the World Food Programmed did use private security contractors to escort relief supplies to vulnerable populations in the conflict-affected areas. In contrast, MSF and ICRC resisted the use of armed protection [13]. When they confronted with the most serious insecurity in Myanmar, they preferred to withdraw or suspend humanitarian assistance.

To the stakeholders in Myanmar, an alternative option is to hire non-armed private security contractors, and mitigate the high risks to its own employees. According to a report issued by the United Nations, it used unarmed private security companies in 12 countries [14]. On the one hand, this mitigates the potential risks to UN employees. On the other hand, the costs related to the recruitment of private security contractors are significantly lower than those for hiring United Nations employees [15]. However, effective legal mechanisms reportedly do not exist to investigate the human right abuses caused by private security contractors. 


\section{Policy Implication}

In Myanmar, it's urgently needed to stress the use of joint funding partnership in situations of conflict. The government has transferred a number of government-delivered services to the private sector, such as telecommunications, ports, water supply, railways, and airports. In the conflict-affected areas of Myanmar, resource is always constrained. As a result, the private security companies and contractors have been taking over some humanitarian functions in the borderlands.

In view of this, the international community should be ready to public-private partnership, which not only bridges the divide between theory and practice in the field of humanitarian assistance, but also mediates differing interests to reach a broad consensus on what is in the best interest of the stakeholders. In fact, the private sector's good relations with both sides has allowed it to play an essential role initially as a facilitator for peace talks. At present, all the Kachin Independence Organization's peace talks with the Myanmar government were mediated and facilitated by the prominent businessmen, who have vested interests in industrial or resource extraction in the conflict-affected areas of Myanmar [16]. For example, Peace Creation Group formed by Kachin businessmen in 2012 assisted ceasefire negotiations between the Myanmar government and Kachin Independence Organization. They have been instrumental in communicating between both parties [17].

\section{Conclusion}

In countries like Myanmar, promoting humanitarian assistance in conflict-affected Areas, and realizing peace between the Myanmar government and ethnic-based militias, needs thoughtful consideration to public-private partnership. Although public-private partnership is an alternative option to the mentioned-above challenges, the involvement of the private sector (e.g., private security companies) in delivering public service, requires an adequate regulatory framework be put in place.

\section{Acknowledgments}

The research for this article was financially supported by the Gerda Henkel Foundation, Grant No. AZ 02/KF/15.

\section{References}

[1] Donini, Antonio. The Golden Fleece: Manipulation and Independence in Humanitarian Action. Sterling, Va.: Kumarian Press. 2012, p.119.

[2] South, Ashley. "Armed Groups and Political Legitimacy”, Myanmar Times. http://www.mmtimes.com/index.php/home-page/143-editor-s-pick/10803-armed-groups-and-p olitical-legitimacy-2.html. 23 June 2014. Accessed July 282016.

[3] Landmine and Cluster Munition Monitor. Landmine Monitor 2013, 2013. http://www.the-monitor.org/en-gb/reports/2013/landmine-monitor-2013.aspx, Accessed July 28 2016.

[4] Arterbury, John. “A Long War's Lingering Reminder”. Karen News. http://karennews.org/2014/04/a-long-wars-lingering-reminder.html. April 4, 2014. Accessed July 28, 2016.

[5] "Myanmar (Burma): Over 40 townships in danger of landmine accidents". Thai News Service (Bangkok, Thailand). March 22, 2016.

[6] "Myanmar landmine blast wounds German tourists, guide”. Agence France-Presse. April 27, 2016. 
[7] Dannreuther, Roland. International Security: The Contemporary Agenda. Chichester: Polity Press. 2013, p.83.

[8] “Myanmar Grants Four Foreign Investment Proposals”. Xinhua News Agency. June 29, 2016.

[9] Win, Su Phyo and Kean, Thomas. "Revised Farmer Protection Law Quietly Comes into Effect”, Myanmar Times. http://www.mmtimes.com/index.php/in-depth/8688-revised-farmer-protection-law-quietly-com es-into-effect.html, November 3, 2013. Accessed July 28, 2016.

[10]Khin, Han Oo. "Demand Jumps for Private Security Services”. Myanmar Times. http:/www.mmtimes.com/index.php/business/5856-demand-jumps-for-private-security-service s.html, December 7, 2009. Accessed July 28, 2016.

[11]Information on: http://www.phoenixelitesecurity.com

[12]Paddon, Emily and Owen, Taylor. "Whither Humanitarian Space? The Cost of Integrated Peacebuilding in Afghanistan”. In Perrin, Benjamin. Modern Warfare: Armed Groups, Private Militaries, Humanitarian Organizations, and the Law. Vancouver: UBC Press. 2012, pp.280-281.

[13]Perrin, Benjamin. "Private Security Companies and Humanitarian Organizations: Implications for International Humanitarian Law”. In Perrin, Benjamin. Modern Warfare: Armed Groups, Private Militaries, Humanitarian Organizations, and the Law. Vancouver: UBC Press. 2012, pp.132-133.

[14]United Nations. "Report of the Working Group on the use of mercenaries as a means of violating human rights and impeding the exercise of the right of people to self-determination”. A/69/338.

[15]United Nations. "Report of the Working Group on the use of mercenaries as a means of violating human rights and impeding the exercise of the right of people to self-determination". A/69/338.

[16]Burma News Internaonal. “Deciphering Myanmar's Peace Process: A Reference Guide 2013”. http://bnionline.net/images/2013/pdf/Deciphering-Myanmar\%E2\%80\%99s-Peace-Process-ForWeb.pdf. 2013. Accessed July 28, 2016.

[17]Burma News International. Deciphering Myanmar's Peace Process: A Reference Guide. http://www.burmalibrary.org/docs14/Deciphering-Myanmar-Peace-Process-ocr-tu-red.pdf.

2013. Accessed July 28, 2016. 